\title{
IMPLICIT PUBLIC DEBT THRESHOLDS: 2017 AN EMPIRICAL EXERCISE FOR THE CASE OF SPAIN
}

Javier Andres, Javier J Perez

and Juan A Rojas

Documentos de Trabajo. N. 1701

\section{BANCODE ESPANAA}

\author{
Eurosistema
}


IMPLICIT PUBLIC DEBT THRESHOLDS: AN EMPIRICAL EXERCISE

FOR THE CASE OF SPAIN 
IMPLICIT PUBLIC DEBT THRESHOLDS: AN EMPIRICAL EXERCISE FOR THE CASE OF SPAIN ${ }^{(*)}$

\author{
Javier Andrés \\ UNIVERSITY OF VALENCIA \\ Javier J. Pérez \\ BANCO DE ESPAÑA \\ Juan A. Rojas
}

ESM

$\left.{ }^{\star}{ }^{\star}\right)$ The views expressed in this paper are the authors' and do not necessarily reflect those of the Banco de España, the Eurosystem or the ESM. We wish to express our thanks for the helpful comments of participants - in particular Alexander Mahle, Pietro Rizza, Francesco Caprioli, Alberto González-Pandiella and Lukas Reiss - at the following meetings: Banca d'Italia Public Finance WS (Rome, 2016), EEP (Girona, 2014), IIPF (Taormina, 2013), EEA (Gothenburg, 2013), WGPF WS (Bratislava, 2012), WGEM meeting (Brussels, 2012) and Public Finance WS at the EC (Brussels, 2011). Corresponding author: Javier J. Pérez (javierperez@bde.es). 
The Working Paper Series seeks to disseminate original research in economics and finance. All papers have been anonymously refereed. By publishing these papers, the Banco de España aims to contribute to economic analysis and, in particular, to knowledge of the Spanish economy and its international environment.

The opinions and analyses in the Working Paper Series are the responsibility of the authors and, therefore, do not necessarily coincide with those of the Banco de España or the Eurosystem.

The Banco de España disseminates its main reports and most of its publications via the Internet at the following website: http://www.bde.es.

Reproduction for educational and non-commercial purposes is permitted provided that the source is acknowledged.

(c) BANCO DE ESPAÑA, Madrid, 2017

ISSN: 1579-8666 (on line) 


\section{Abstract}

We extend previous work that combines the Value at Risk approach with estimation of the correlation pattern of the macroeconomic determinants of public debt dynamics by means of Vector Auto Regressions (VARs). These estimated models are used to compute the probability that the public debt ratio exceeds a given threshold, by means of MonteCarlo simulations. We apply this methodology to Spanish data and compute time-series probabilities to analyse the possible correlation with market risk assessment, measured by the spread over the German bond. Taking into account the high correlation between the probability of crossing a pre-specified debt threshold and the spread, we go a step further and ask what would be the threshold that maximises the correlation between the two variables. The aim of this exercise is to gauge the implicit debt threshold or "prudent debt level" that is most consistent with market expectations as measured by the sovereign yield spread. The level thus obtained is consistent with the medium-term debt-to-GDP ratio anchor of $60 \%$ of GDP.

Keywords: public debt, early warning indicators, fiscal sustainability.

JEL classification: H63, H68, E61, E62. 


\section{Resumen}

Este artículo contribuye a la literatura que analiza los determinantes fundamentales de la dinámica de la deuda pública combinando modelos de vectores autoregresivos (VAR) y las ideas de la aproximación de Value at Risk. Los modelos que se estiman se usan para calcular la probabilidad de que la ratio de deuda pública sobre el PIB exceda un cierto umbral predeterminado de deuda, mediante simulaciones de Montecarlo. Se aplica la metodología al caso español, y se calculan de manera recursiva las series temporales de probabilidades y sus correlaciones con un indicador de riesgo de mercado (medido como el diferencial de rentabilidad del bono español a diez años con su equivalente alemán). A partir de estas correlaciones, se computa cuál sería el umbral de deuda para el que se maximizaría la correlación entre las dos variables (probabilidades y diferencial). El propósito de este ejercicio es calibrar el límite implícito de deuda o "nivel prudente de deuda pública» que refleja de manera más adecuada las expectativas del mercado, medidas por el diferencial de riesgo soberano. El nivel que se obtiene es coherente con la ratio de deuda pública sobre PIB del $60 \%$ del PIB que actúa como ancla en el marco europeo de reglas fiscales.

Palabras clave: deuda pública, indicadores de alerta temprana, sostenibilidad de las finanzas públicas.

Códigos JEL: H63, H68, E61, E62. 


\section{Introduction}

This paper presents an empirical exercise that aims at highlighting the dependence of the public debt level that a given country can afford or maintain in the medium-term on the macroeconomic and fiscal fundamentals of the country. Some countries are able to maintain a high level of public debt over long and sustained periods of time while keeping normal access to the international markets, while others have to keep a significant public debt buffer against adverse macroeconomic and fiscal developments. A standard result of the extant literature is that public debt should act as a shock absorber to help smooth the response of adverse shocks on budgetary variables, in particular to avoid drastic increases in tax rates or decreases in spending in downturns. Nevertheless, this result is obtained under perfect access to markets by the government. If a given government, on the contrary, were subject to market pressure and limited market access, then even under a situation of economic distress a given country may end up implementing a pro-cyclical fiscal consolidation plan.

In this regard, some empirical and theoretical literature suggest that a country-specific "affordable" or "prudent" public debt level exist, beyond which a given country would be more vulnerable and/or subject to a higher level of fiscal stress and market scrutiny. ${ }^{1}$ Rational markets should be able to assess the evolution of fundamentals and thus impose tighter debt limits on countries with weaker and/or more volatile fundamentals, in particular with lower mean GDP growth rates or higher economic volatility. ${ }^{2}$ One particular branch of the latter literature discusses the main determinants of the maximum level of debt that a country can afford without defaulting, as well as the non-linear behavior of financing costs once the debt to GDP ratio of a country approaches that level. ${ }^{3}$

Not surprisingly, the idea of a "prudent" government debt level has also been touched upon by the literature dealing with the analysis of public debt sustainability. In particular,

\footnotetext{
${ }^{1}$ See e.g. Fall and Fournier (2015), and the references quoted therein. This literature is different, though related, to that dealing with the optimality of public debt, as Woodford (1990), Aiyagari and McGrattan (1998), Floden (2001), or Desbonnet and Kankamge (2007).

${ }^{2}$ See for example Mendoza and Oviedo (2006) or Hiebert, Pérez and Rostagno (2009).

${ }^{3}$ Along these lines one can classify the literature dealing with the fiscal limit (Bi, 2012, Bi and Leeper, 2013, Ghosh et al., 2015, or Daniel and Shiamptanis, 2013) or that defining the "Maximum Sustainable Debt ratio" (as in Collard, Habib and Rochet, 2015).
} 
among others, Garcia and Rigobon (2004) and Polito and Wickens (2011) combine the Value at Risk approach with the estimation of the correlation pattern of the macroeconomic determinants of public debt dynamics by means of Vector Auto Regressions (VARs). These estimated VARs are then used to compute the probability of the public debt ratio being higher than a given threshold, by means of Montecarlo simulations. By doing so they study to what extent the computed time-varying probabilities are able to correctly predict the dynamics of the stock of public debt over some quarters ahead, with the aim of checking whether they may act as an early warning indicator of the compliance of the public debt level with some reference value, like EU's 60\% Maastricht criteria or, more importantly, the extent of convergence towards a given reference value.

Our paper is linked to the last piece of the literature. Nevertheless, we move one step forward and analyze the correlation of the probability-type measures defined in the previous paragraph with market risk assessment, as captured by the sovereign debt spread. We estimate a high correlation between the probability of passing a pre-specified debt threshold and the spread, and we identify the threshold that maximizes the correlation between the two variables. The aim of this exercise is to gauge the implicit debt threshold which is "more consistent" with market expectations, approximated by the spread. To illustrate this point, we choose the case of Spain. ${ }^{4}$ This is an interesting case because, despite the fact that the country enjoyed a comparatively low public debt level within the euro area in general (see Figure 1) over most of the recent crisis (and more so within the group of peripheral countries), it was subject to distinctive market pressure since 2009 and was routinely grouped among "high-debt countries" by the international economic press. ${ }^{5}$

The finding that our measure of risk is highly correlated with the sovereign spread raises the issue of the utility of the former in real-time monitoring, given that the latter, at the

\footnotetext{
${ }^{4}$ For an analysis of the evolution of Spanish public debt over the crisis see Gordo, Hernández de Cos and Pérez (2013).

${ }^{5}$ Against this background, it is not surprising to acknowledge that Spain, among several countries in the euro area, passed at the end of 2011 a reform of its Constitutional Law in order to incorporate explicit public debt limits. Indeed, following an urgent procedure the Parliament approved on 8 September 2011 a reform of the Constitution to include a public debt rule that sets the reference level of $60 \%$ specified in the Treaty on the European Union as an explicit limit, with the ultimate end of anchoring medium-term markets' expectations (see Hernández de Cos and Pérez, 2013; and Martí and Pérez, 2015).
} 
Figure 1: Evolution of the general government debt-to-GDP ratio in selected euro area countries.

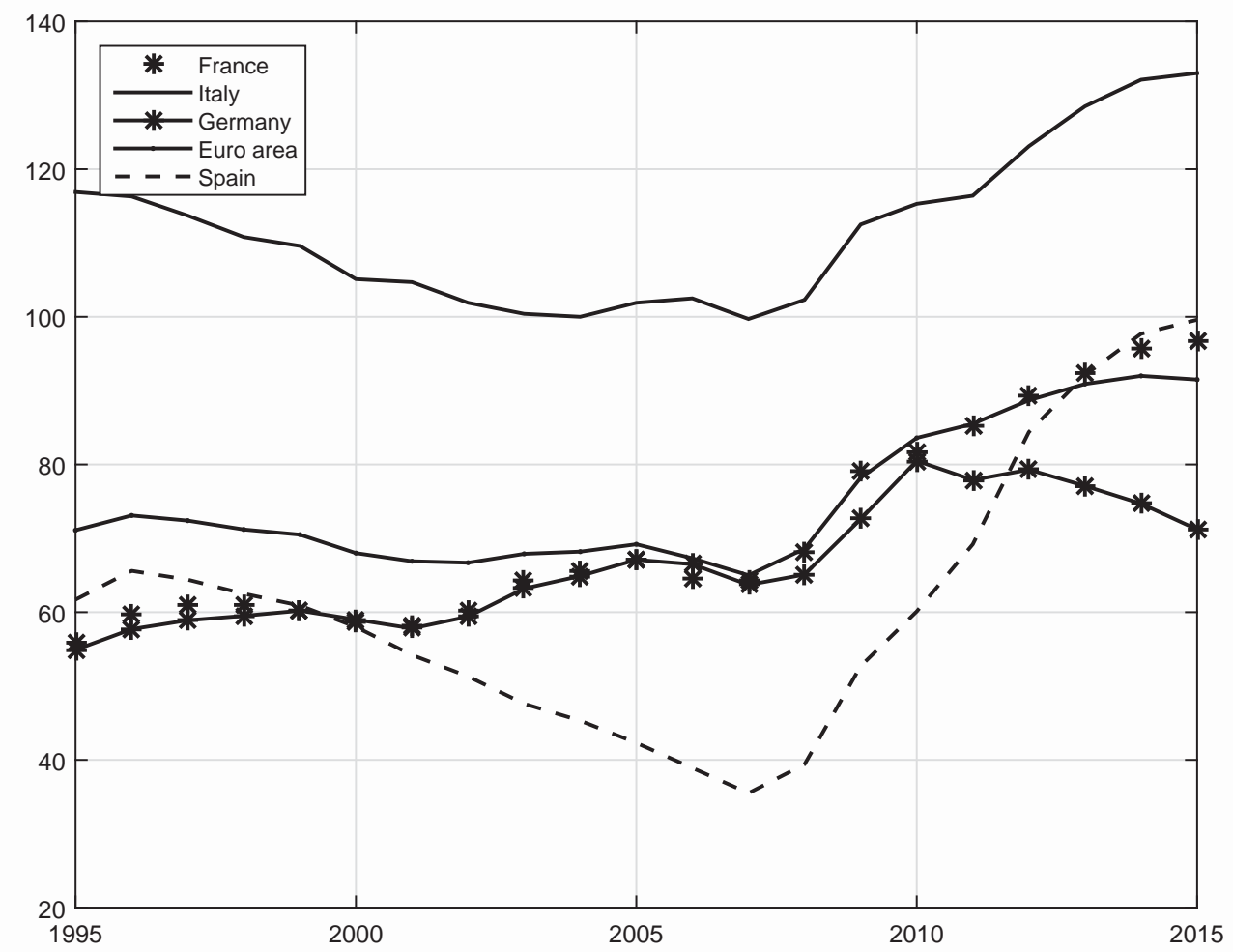

end of the day, is available on a daily basis. In this respect, we argue that the advantage of complementing the standard analysis with the probability measures we compute is twofold. First, it is a measure based on fundamentals, and thus not subject to market volatility. Second, we show that our measures Granger-cause the information contained in the spread, and thus, in a sense, do contain advanced information that is only reflected in the market measures with some delay.

We conduct our empirical exercise for the period starting in the mid-1990s up until the fourth quarter of 2015, while using a sample that dates back to the 1970s for the estimation of our models. Certainly, it is worth mentioning that the behaviour of the sovereign spreads in the latter part of the sample (since 2013) is likely to have been influenced by two key factors, beyond the standard determinants highlighted by the literature. First and foremost, the introduction of non-standard monetary policy measures by the ECB, including massive buy-outs of public debt. Second, the establishment of the European Stability Mechanism as a backstop that intended to mute sovereign debt risks. 
Figure 2: The evolution of Spanish public debt: 1970-2015.

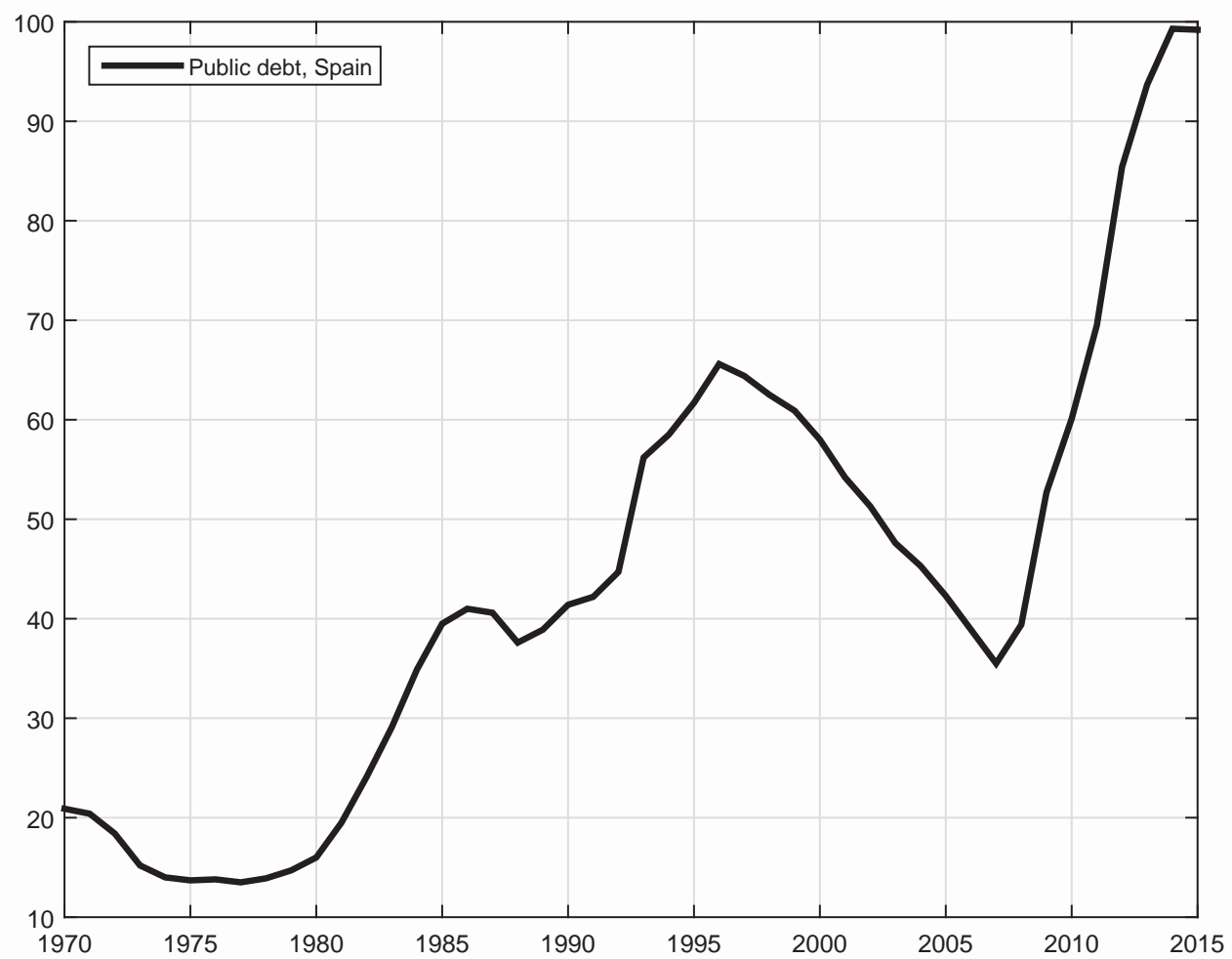

The rest of the paper is organized as follows. In Section 2 we describe the evolution of public debt in Spain in the past few decades and provide some stylized facts. In Section 3 we discuss the data and the methodology used in the empirical analysis, while in Section 4 we discuss the main results. Finally, in Section 5 we present some conclusions.

\section{Some stylized facts}

In the case of Spain, as can be seen in Figure 2 the maximum level of debt as a percent of GDP in the period 1970-2007 was reached in 1996 (65.6\% of GDP). After the 1996 maximum, public debt entered into a downward path until reaching a minimum of $35.5 \%$ in 2007 . In the period 2008-2014, nevertheless, debt increased substantially to reach $99.3 \%$, the maximum of the time series in the period 1970-2014, to marginally fall in 2015 to $99.2 \%$. In relative terms, the Spanish public debt-to-GDP ratio represented in 2012 about $95 \%$ of the euro area ratio, similar to its relative level in 1996, but it outpaced it in 2014 . 
From a backward looking perspective, it is apparent that Spanish public debt increased in times of economic recession, but showed a significant downward rigidity in post-crisis times, at least until the mid 1990s. Debt remained stable as a ratio to GDP during the 1970s. Between 1980 and 1987 public debt increased by close to 30 percentage points of GDP, and got stabilized at 1987's level till 1991. This was the starting point for the second big increase in the sample period analyzed, as the outburst of the 1993 crisis pushed upwards public debt again, in such a way that the stock of government debt increased by some 25 percentage points between 1992 and 1996. This hysteresis-like behavior witnessed over the decade and a half that started in 1980 was curbed in the subsequent 1997-2007 period. In the latter 10-year period, sovereign debt was reduced by above 25 percentage points of GDP, only to increase again substantially in the last part of the sample.

It is worth looking at the prolonged episode of debt reduction that started in the late 1990, and the subsequent increase in debt, through the lenses of the government budget constraint. Let $Y_{t}$ be real GDP at $t$ and let $D_{t}$ be the real value of government debt. The government budget constraint accounts for how the nominal interest rate $i_{t}$, net inflation $\pi_{t}$, net growth in real GDP, $g d p_{t}$, the net-of-interest deficit as a percent of $Y_{t}$, de $f_{t}$, and the deficit-debt adjustment, $D D A_{t}$ combine to determine the evolution of the government debt-to-GDP-ratio,

$$
\frac{D_{t}}{Y_{t}}=\frac{1+i_{t}}{\left(1+\pi_{t}\right)\left(1+g d p_{t}\right)} \frac{D_{t-1}}{Y_{t-1}}+d e f_{t}+\frac{D D A_{t}}{Y_{t}}
$$

were the nominal yield $i_{t}$ and the real stock of debt $D_{t}$ are averages of pertinent objects across terms to maturity. A standard, approximated version, suitable for accounting decomposition of the fundamental determinants of debt, takes the form

$$
\frac{D_{t}}{Y_{t}}=\frac{D_{t-1}}{Y_{t-1}}+\left(i_{t}-\pi_{t}-g d p_{t}\right) \frac{D_{t-1}}{Y_{t-1}}+d e f_{t}+\frac{D D A_{t}}{Y_{t}}
$$

With this decomposition at hand it is possible to analyze the determinants of changes in the debt-to-GDP ratio. In the upper panel of Figure 3 we decompose these determinants for each year over the period 1996-2015. Focusing in a first stage in the period 1996-2007, the primary balance contributed to an average debt reduction of 2.9 percentage points per year, 
Figure 3: The determinants of the change in the Spanish public debt-to-GDP ratio.

\section{Year-by-year changes}

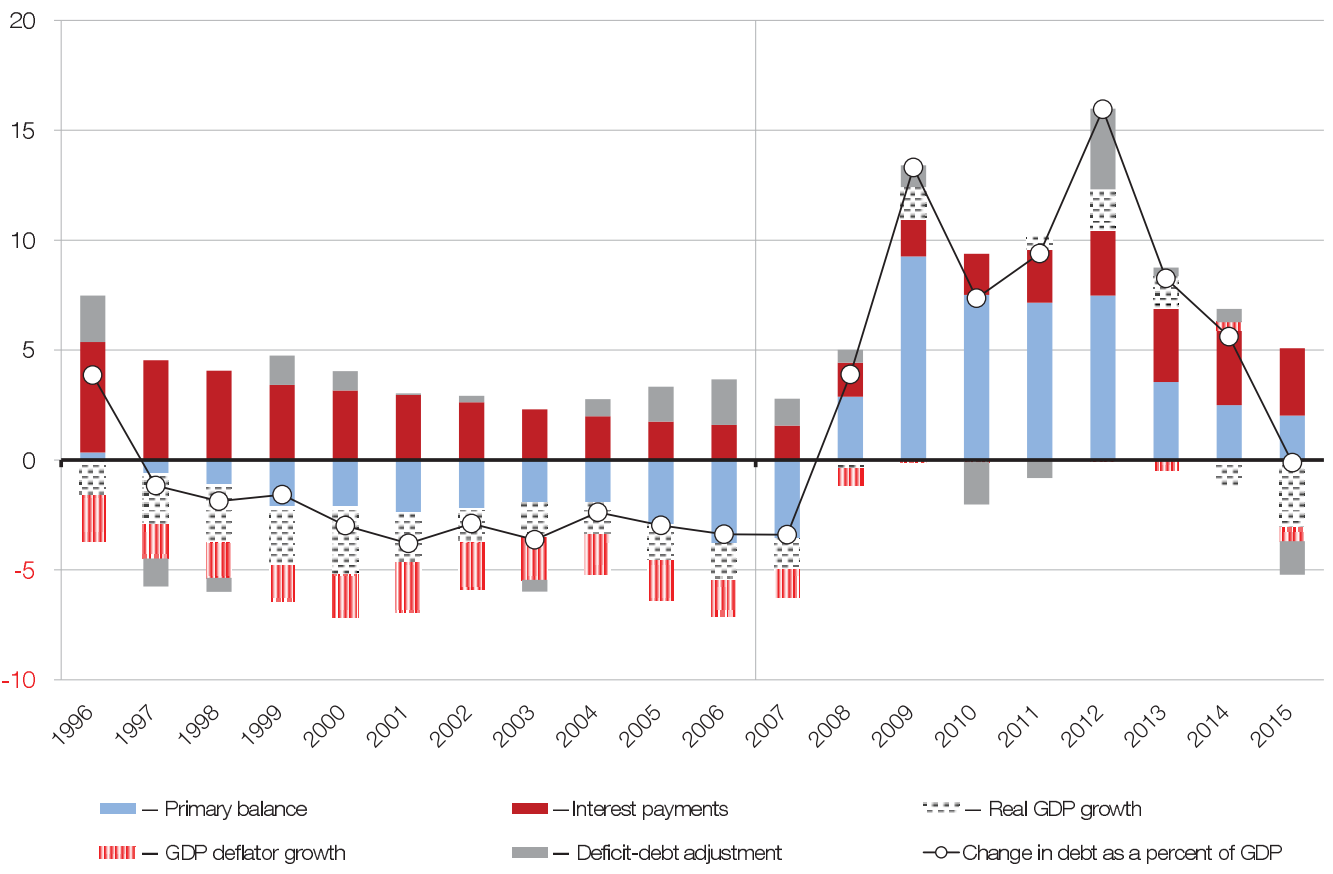

\section{Cumulative changes}

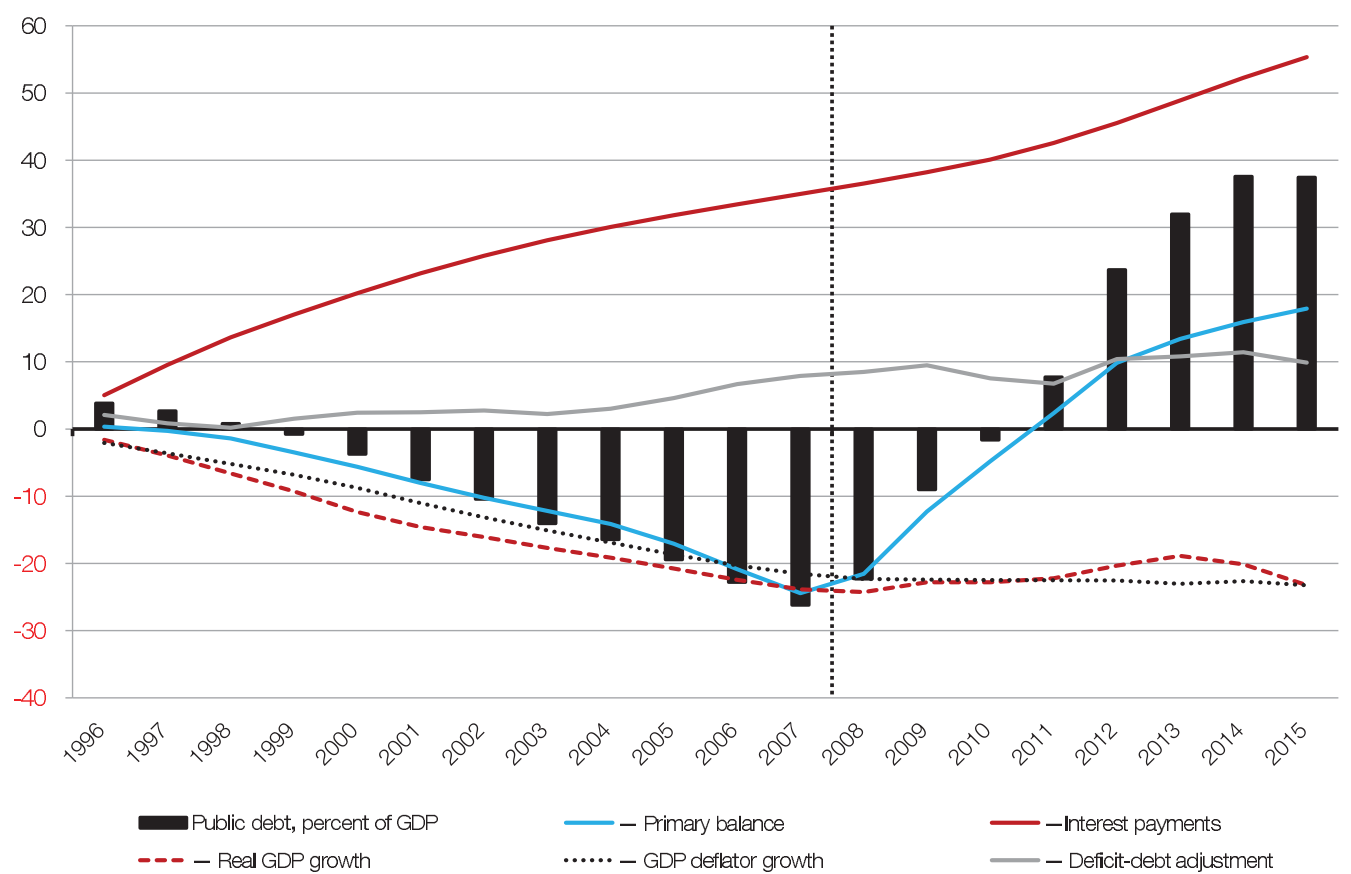


an amount larger in size than the average contribution of real GDP (2.0 percentage points per year on average) and inflation (1.8 points per year on average). These three positive factors were partly compensated by an average 0.7 points per year debt-increasing contribution stemming from deficit-debt adjustments, and the interest payments, that amounted to some $2.9 \%$ of GDP per year on average. As regards the 2008-2015 period, the sizeable increase in debt was basically due to the worsened primary balance (5.3 pp per year), interest payments (2.5 pp per year), and the adverse contribution of deficit-debt adjustments. To reinforce our exposition, in the lower panel of Figure 3, in turn, we show the same information as before, but cumulated, i.e. calculated by means of equation:

$$
\frac{D_{t}}{Y_{t}}=\frac{D_{t-\tau}}{Y_{t-\tau}}+\sum_{s=0}^{\tau-1}\left[\left(i_{t-s}-\pi_{t-s}-g d p_{t-s}\right) \frac{D_{t-s-1}}{Y_{t-s-1}}+d e f_{t-s}+\frac{D D A_{t-s}}{Y_{t-s}}\right]
$$

Between 1996 and 2007, the 26 percentage points of public debt reduction can be broken down as follows: (i) 35 percentage points of reduction due to the adjustment of the primary balance; (ii) 23.9 points of reduction due to favorable real GDP growth; (iii) 21.6 percentage points of reduction due to inflation; (iv) these three factors more than compensated the increase of 35 points due to the interest payments during the period, and the 7.9 percentage points due to the deficit-debt adjustments. On the contrary, in the course of the eight years that span from 2008 to 2015, the abrupt reversal of all positive factors, most notably the significant primary deficits, undid the results of the 1997-2007 consolidation period.

In the most recent period, the debt-increasing contribution of the interest burden veils a favorable evolution of the implicit interest rate. Interestingly, implicit interest rate dynamics, that averages interest rates of newly issued debt, including that refinanced, and rates of nonmaturing debt issued in the past, contributed to contain the increase in the public debt ratio in 2008, 2009 and 2010, only turning to a positive contribution in 2011, when rates at issuance increased substantially. The effect of ECB's monetary policy measures on the interest burden of the government becomes clear in the last part of the sample (see Figure 4).

After this brief backward-looking description of the contributions of the main determinants of public debt to its evolution, in the subsequent Section we turn to the analysis of 
Figure 4: The determinants of the change in the interest payments to GDP ratio

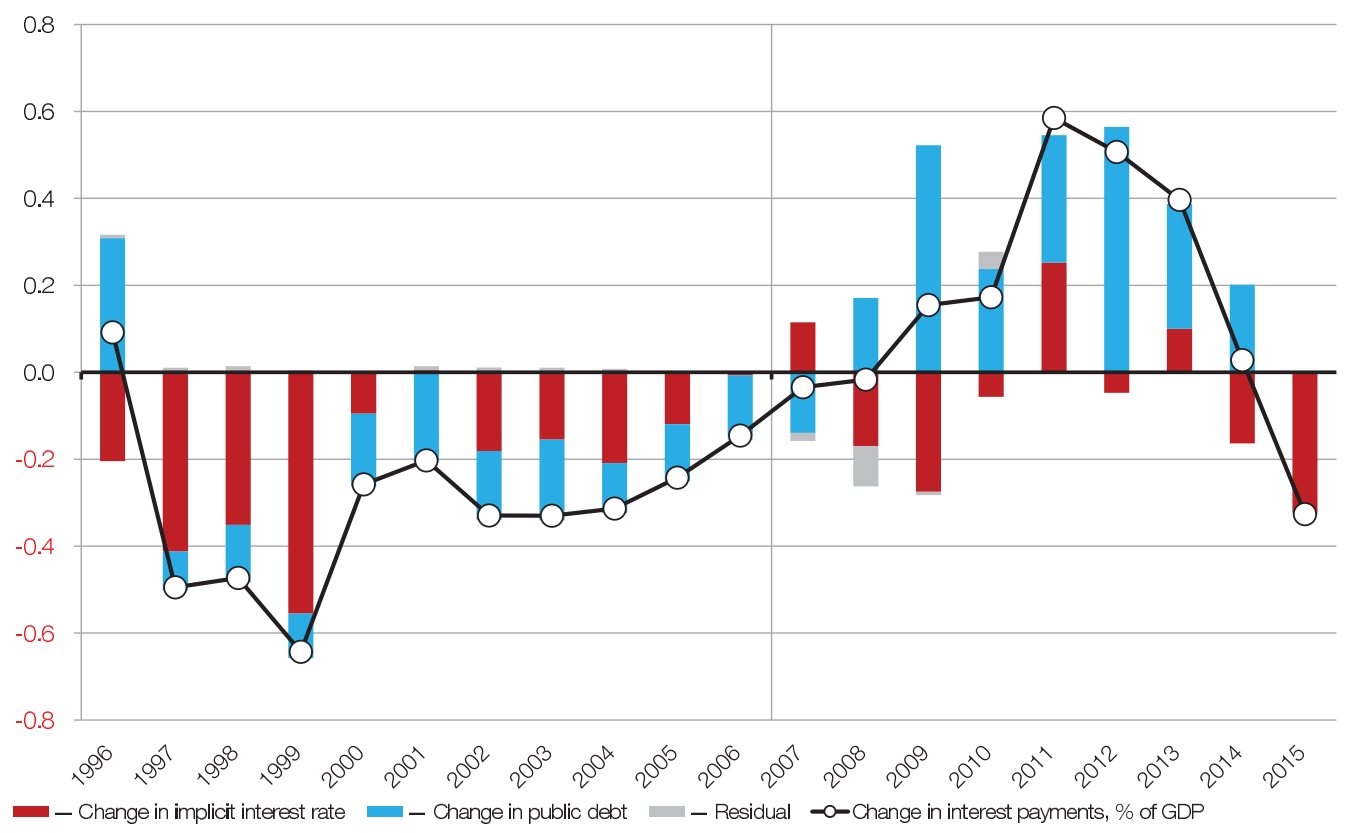

the role of fundamentals in public debt evolution, but from a forward-looking, model-based point of view.

\section{Empirical methodology and data}

\subsection{The data}

We use quarterly data from the first quarter of 1970 to the fourth quarter of 2015 of the following variables: the the stock of public debt, the government primary deficit over GDP, the inflation rate, the implicit interest rate (computed as the ratio between the interest payments in a quarter and the stock of public debt of the previous period), and the growth rate of GDP in real terms. Concerning the spread, the data used covers the period from 1980Q1 to 2015Q4 and it is computed as the difference between the Spanish 10-year government bond yield and the German one, in both cases averaged over the quarter from daily data, taken from Bloomberg. The data source of the macroeconomic variables is the Spanish National Statistical Institute (INE), while fiscal variables are taken from de Castro et al. (2016). 


\subsection{Outline of the methodology}

The approach to assess the dynamics and sustainability of public debt is based on the sequential estimation of a Vector autoregression model, updated each period. As claimed recently by Polito and Wickens (2011) this is instrumental for the problem at hand in that it exploits the well-documented advantages of time-series models for forecasting in the short run (see e.g. Stock and Watson, 2001), and also due to the fact that time-series models tend to give better forecasts than structural models, particularly in the presence of structural breaks (see e.g. Clements and Hendry, 2005). Even though we take an agnostic view and estimate unrestricted VARs (structural models can be written as restricted VARs), we use the theory to guide our selection of variables. In particular we use the government budget constraint, as in (1) to select the variables to be included in the analysis.

More in detail, the procedure consists of the following steps. First, given an initial sample size, a VAR is estimated using the variables that enter into the public debt equation, which in its simplest form are: the ratio of the primary public deficit over GDP, the nominal interest rate, the inflation rate and the growth rate of GDP. Second, given the estimated parameters of the VAR and the corresponding variance-covariance matrix of the errors, a large number of Monte-Carlo simulations are performed to obtain a large number of realizations of the innovations and the associated realizations of the macroeconomic fundamentals of the debt equation. This step entails the computation of the implied debt-to-GDP ratio for different time horizons depending on the criteria of interest, where the period-by-period government budget constraint, expressed as a ratio to total GDP takes its non-linear form as in (1).

The procedure can be applied sequentially and allows for the calculation of the probabilistic distribution of the debt ratio for each quarter of the projection. Notice that at each point in time $t$ the procedure uses the macroeconomic data available up to $t-1$ which are the initial conditions of the relevant variables from which the simulated paths depart, and consequently the exercise can be used to out-of-sample monitor the evolution of public debt both in the short and the long term. 


\subsection{VAR model}

The first step of the approach entails the sequential estimation of a standard Vector Autorregression Model of the following form

$$
Y_{t}=\mu_{y}+\beta t+B(L) Y_{t-1}+U_{t}
$$

where

$$
Y_{t}=\left(g d p_{t}, \pi_{t}, i_{t}, d e f_{t}\right)
$$

$\mu_{y}$ and $t$ deterministic terms (constants and trends), and $U_{t}$ is the vector of reduced-form residuals which are assumed to be distributed according to a multinomial distribution with zero mean and covariance matrix $\Omega$, i.e. $U_{t} \sim N(0, \Omega)$. In order to allow for enough observations at the beginning of the sample, the sequence of models is estimated over a rolling window, with the initial sample being 1970Q2-1993Q4. Then, one quarter is added at a time until reaching the whole sample (1970Q2-2015Q4).

\subsection{The empirical distribution function of debt levels}

The sequential estimation of the VAR and the computation of the simulated paths for public debt generates, at each point in time, an empirical distribution function of debt levels. This distribution function, that also depends on the simulation horizon, can be used to monitor the evolution of public debt in both the short and the long term by computing the corresponding moments of the simulated data. We denote as $F_{t}^{T}\left(d \mid I_{t-1}\right)$ the empirical cumulative distribution function of debt realizations of length $T$ conditional on the information available up to period $t-1\left(I_{t-1}\right.$, composed of past data and the estimated parameter coefficients of the VAR model)

For illustrative purposes Figure 5 displays the cumulative distribution of debt at different simulation spans (one quarter, one year and two years) when the associated VAR is estimated with data until 2011Q4 and with data up to 2015Q4. Notice that at short simulation's horizons, debt outcomes are distributed tightly around the mean and as the projection horizon lengthens, uncertainty increases in such a way that the distribution becomes more fattailed and more extreme outcomes cannot be ruled out. Interestingly, public debt simulations 
Figure 5: Empirical CDF with alternative information sets.

With information up to 2011Q4

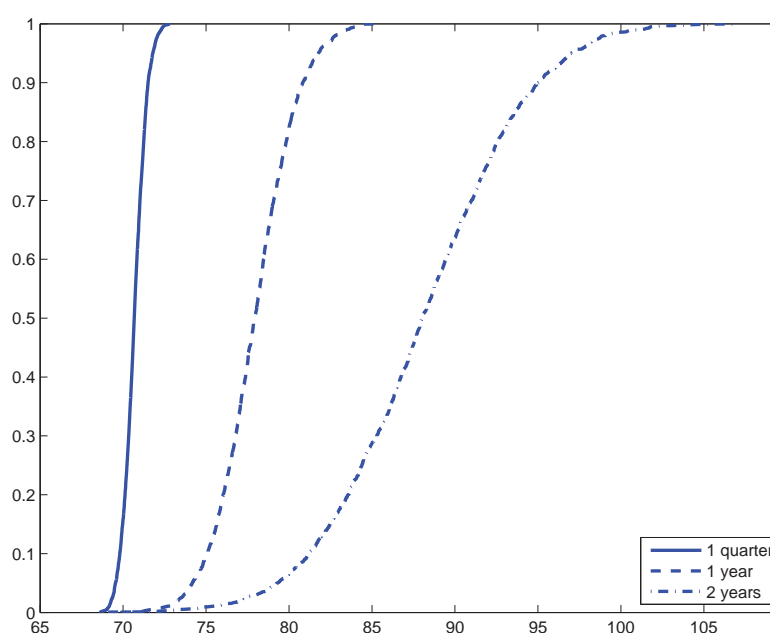

With information up to 2015Q4

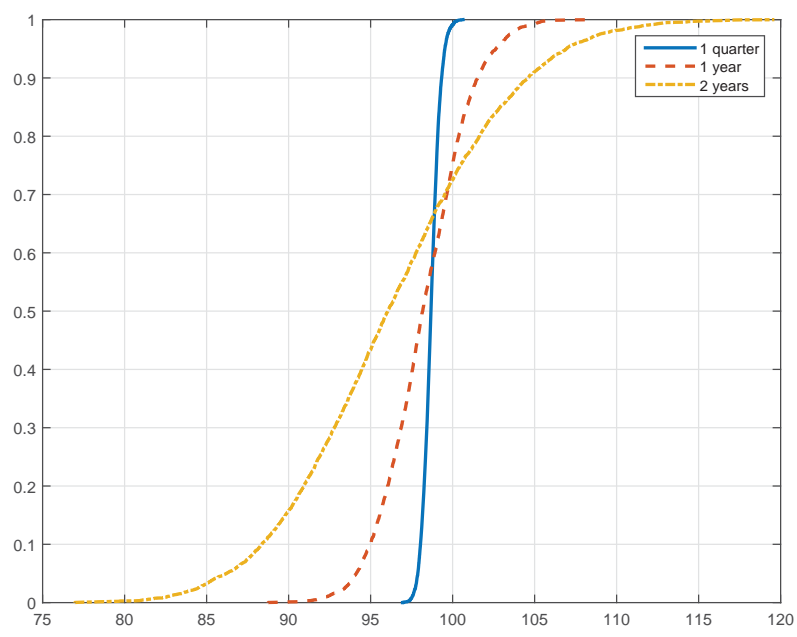

performed with information up to the end of 2011 anticipated an increase of debt at all horizons, while for the exercise performed with the sample up to 2015Q4 there is more heterogeneity, with a non-negligible set of simulated paths indicating a reduction of public debt.

The distributions generated could be used to perform debt projections starting at the end of the sample. More generally, in order to assess the forecasting performance of the procedure in the very short run when compared to the data, Figure 6 displays the average 1-quarter out-of-sample forecast of the macro fundamentals and the public debt over GDP against the observed data of the corresponding variable. The visual inspection of the graph indicates that the model correctly approximates the evolution of the main macroeconomic fundamentals in the very short term (1 quarter ahead). The out-of-sample performance ability of the model to forecast the dynamics of public debt is illustrated in Table 1 in which we compare the observed evolution of this item in the data against the forecast implied by the model at different time horizons. In particular, using the information available up to the fourth quarter of 2008, we present in panel A the expected dynamics of public debt in each quarter of 2009 and 2010 implied by the model, while in panel B we take the fourth quarter of 2010 as forecast origin and display the forecasts for 2011 and 2012, and in panel C the 
Figure 6: Data (solid lines) versus one-quarter-ahead forecasts (dashed lines).
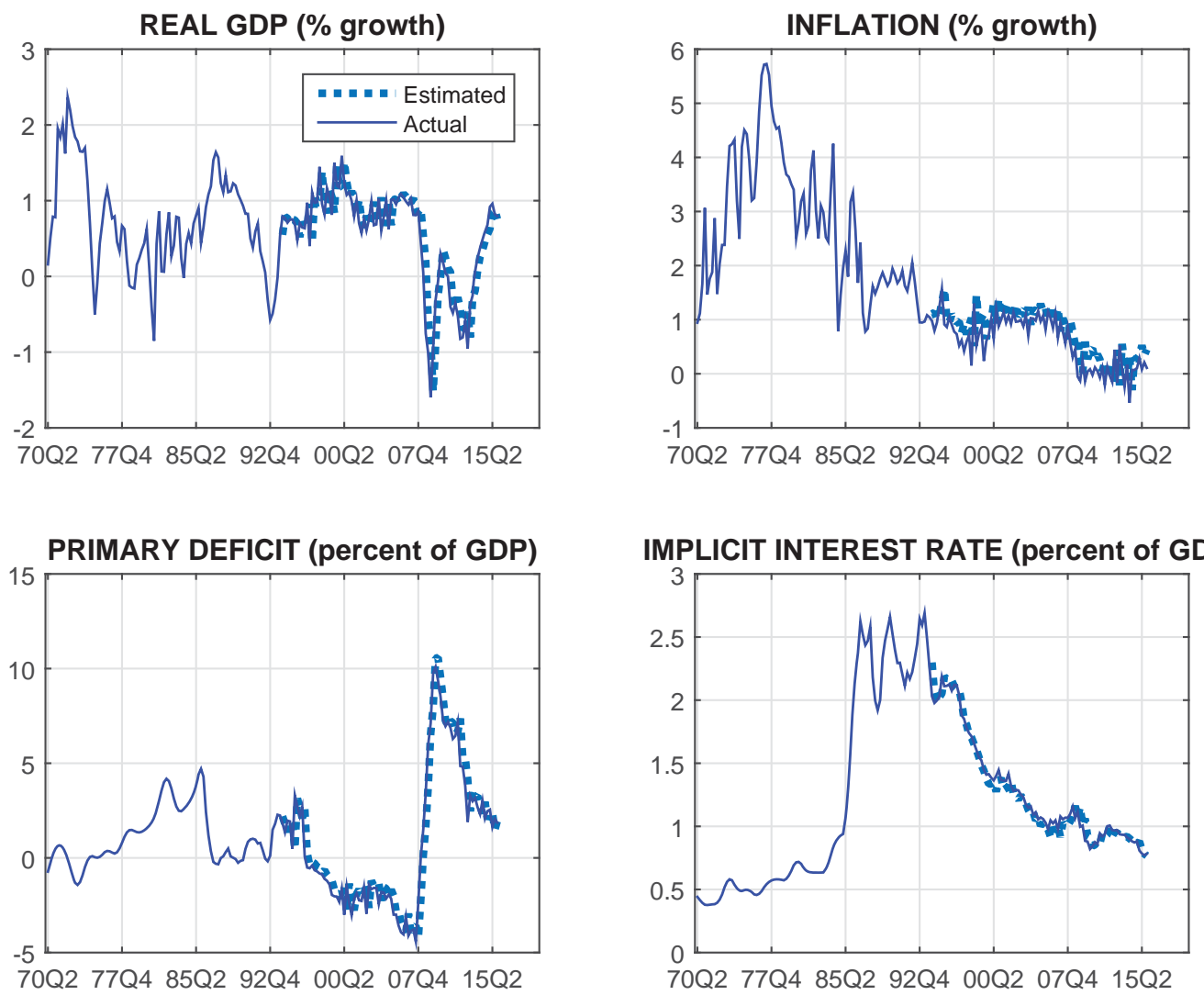

projections with information up to 2013Q4. As mentioned before, the standard deviation of the forecast increases at longer horizons. Beyond this illustrative forecast paths, the short-, medium-, and long-term projections of the VARs beat simple benchmark models like the standard random walk and univariate alternatives to extrapolate public debt. ${ }^{6}$

\subsection{The risk measure of public debt and the "prudent" medium- term level}

Apart from the calculation of forecasts, the time dependent empirical distribution function can also be used to monitor the expected evolution of public debt in probabilistic terms. In

\footnotetext{
${ }^{6}$ The results are available from the authors upon request.
} 
Table 1: Public debt forecasts at the beginning of the economic crisis (2008Q1), in the midst of the euro area sovereign debt crisis (2010Q4), and in the recovery phase (2013Q4).

Panel A. Forecast origin 2008Q4.

\begin{tabular}{lcccccccc}
\hline & \multicolumn{4}{c}{2009} & \multicolumn{5}{c}{2010} \\
& Q1 & Q2 & Q3 & Q4 & Q1 & Q2 & Q3 & Q4 \\
\cline { 2 - 9 } Actual & 42.6 & 46.7 & 50.4 & 52.4 & 55.3 & 56.5 & 58.4 & 59.5 \\
Forecasts: Minimum & 39.7 & 46.0 & 52.1 & 55.6 & 55.2 & 55.5 & 53.7 & 52.6 \\
Forecasts: Mean & 40.7 & 49.0 & 56.7 & 62.2 & 63.9 & 64.7 & 66.8 & 70.1 \\
Forecasts: Maximum & 41.6 & 51.9 & 61.0 & 69.2 & 75.0 & 75.6 & 81.9 & 88.7 \\
Forecast: Standard deviation & 0.26 & 0.66 & 1.15 & 1.77 & 2.38 & 3.02 & 3.84 & 4.76
\end{tabular}

Panel B. Forecast origin 2010Q4.

\begin{tabular}{lccccccccc}
\hline & \multicolumn{3}{c}{2011} & \multicolumn{5}{c}{2012} \\
& Q1 & Q2 & Q3 & Q4 & Q1 & Q2 & Q3 & Q4 \\
\cline { 2 - 8 } Actual & 62.5 & 66.6 & 68.8 & 69.6 & 72.5 & 76.8 & 79.6 & 81.2 \\
Forecasts: Minimum & 60.4 & 64.3 & 67.5 & 71.6 & 72.7 & 72.5 & 75.1 & 66.8 \\
Forecasts: Mean & 61.7 & 67.6 & 73.5 & 78.6 & 82.7 & 87.8 & 95.3 & 92.6 \\
Forecasts: Maximum & 62.9 & 70.4 & 78.5 & 86.2 & 94.0 & 103.8 & 115.9 & 116.5 \\
Forecast: Standard deviation & 0.34 & 0.81 & 1.43 & 2.19 & 3.04 & 4.07 & 5.34 & 6.14
\end{tabular}

Panel C. Forecast origin 2013Q4.

\begin{tabular}{lccccccccc} 
& \multicolumn{1}{c}{2014} & \multicolumn{7}{c}{2015} \\
& Q1 & Q2 & Q3 & Q4 & Q1 & Q2 & Q3 & Q4 \\
\cline { 2 - 9 } Actual & 95.1 & 97.6 & 98.3 & 98.4 & 98.5 & 98.9 & 98.5 & 98.5 \\
Forecasts: Minimum & 93.7 & 93.6 & 93.9 & 90.8 & 87.7 & 82.7 & 75.1 & 73.8 \\
Forecasts: Mean & 95.5 & 97.7 & 99.8 & 99.6 & 99.5 & 96.6 & 95.5 & 95.6 \\
Forecasts: Maximum & 97.3 & 102.2 & 106.6 & 110.1 & 113.2 & 112.3 & 117.2 & 120.3 \\
Forecast: Standard deviation & 0.50 & 1.12 & 1.84 & 2.66 & 3.56 & 4.32 & 5.29 & 6.23 \\
& & & & & & & & \\
\hline & \\
Note: Excluding deficit-debt adjustments. Public debt figures in each quarter are normalized by nominal GDP in that \\
quarter, annualized. Thus, the so-computed ratios are different from the standard presentation in which the sum of four
\end{tabular}


Table 2: Correlations between the probability and the spread

\begin{tabular}{cccc} 
& \multicolumn{3}{c}{ Time span } \\
\cline { 2 - 4 } & 10 years & 5 years & 1 year \\
\cline { 2 - 4 } 1994Q1-2015Q4 & 0.74 & 0.69 & 0.51 \\
1994Q1-2007Q4 & 0.84 & 0.72 & 0.29 \\
1999Q1-2013Q2 & 0.79 & 0.74 & 0.53 \\
\hline
\end{tabular}

particular, given the distribution function, it is possible to compute the probability of public debt being higher than a particular threshold $\theta$ some quarters ahead $T$, given the information available at some point in time denoted as $I_{t-1}$. Notice that the sequence of probabilities will be time dependent. Formally, at each point in time $t$ the following probability is computed

$$
p_{t / t-1}^{T}(\theta)=P\left(d>\theta \mid I_{t-1}\right)=1-F_{t}^{T}\left(\theta \mid I_{t-1}\right)
$$

and the sequence of such probabilities $\left\{p_{t / t-1}^{T}(\theta)\right\}$ which will be denoted as $P_{t / t-1}^{T}(\theta)$. As suggested before, one possible way of summarizing the information provided by the time dependent distribution function of public debt level is to compute the probability of observing a debt level above some threshold of interest which is deemed to be critical for its sustainability. An example is the $60 \%$ public debt level of reference for the Stability and Growth Pact and the Spanish Constitution. This exercise, in itself, is useful to monitor compliance with fiscal rules or simulate alternative scenarios of interest, and as such is used in the related literature.

In Table 2 we show the correlations of the probability series for a given arbitrarily chosen threshold (60\%) computed for different time spans, and the 10-year bond spread. The higher correlation is associated with the 10-years horizon, and the probability increases monotonically as the time horizon approaches that of the spread, showing that there seems to be some consistency between the time span of the spread (10 years) and the probabilities computed using the same temporal horizon.

From this point on we move one step forward. One may claim that the probability series computed taking into account a given threshold should be linked to some market-based 
measure of risk in the market for public debt (García and Rigobon, 2004). In our framework this is illustrated in Figure 7, were we plot the recursive probability obtained at each point in time (as measured by the time axis) of breaching the $60 \%$ of GDP debt threshold in 10 years from the forecasts origin, i.e. $P_{t / t-1}^{10 y}(60)$. Interestingly, just by simple inspection some close correlation among the two series becomes evident.

Thus, it seems natural to study the linkages between the measure of risk calculated in (6) and the standard indicator of risk, namely the sovereign bond spread. In this fashion, we calculate the threshold that maximizes the correlation between our risk measure and the sovereign bond spread in order to gauge the implicit debt threshold which is the most consistent with market expectations approximated by the spread. Formally,

$$
\theta^{*}=\arg \max _{\theta} \operatorname{corr}\left(P_{t / t-1}^{T}(\theta), S_{t}\right)
$$

i.e. conditional on the information set available at $t, I_{t-1}$, we solve (7) to get the debt threshold, $\theta^{*}$, relevant for market participants that use as a reference the time horizon $T$. This debt threshold $\theta^{*}$ can be viewed as the one that shapes market participants expectations about the evolution of public finances and then as a market-based index of debt sustainability. As such, this does not imply that debt reaches its "maximum affordable" level, as defined by the fiscal limit (i.e., "...the point beyond which taxes and government expenditures can no longer adjust to stabilize the value of government debt...", Leeper and Walker, 2011), but rather that the debt ratio enters in a region in which the degree of vulnerability of public finances becomes high, possibly with an associated non-negligible probability of debt becoming under stress so that the price of bonds drops dramatically to allow for a risk premium. In that sense, $\theta^{*}$ is more associated to the lower limit of the probability distribution of the fiscal limit itself, beyond which the debt ratio displays a small but non negligible probability of reaching the fiscal limit, thus triggering a non linear response of the spread (Bi, 2012). In the current circumstance in the euro zone, though, such a response is likely to be muted by the fact that a major player in the sovereign debt market is present (i.e. the ECB), as compared to normal periods in which governments are forced to access the market to cover their financing needs. 
Figure 7: The probability $P_{t / t-1}^{10 y}(\theta)$ and the sovereign bond spread.

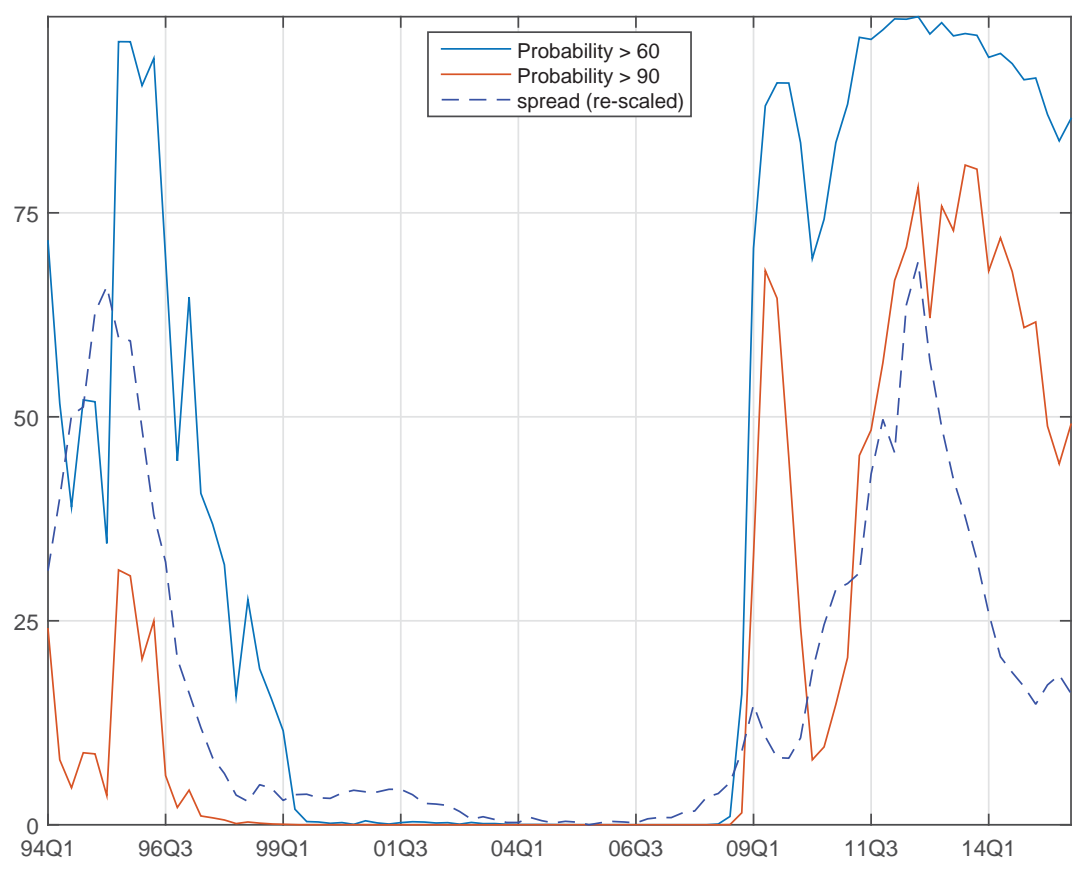

\section{Some empirical results}

The outcome of the implementation of the maximization procedure outlined in the previous Section, is displayed in the left panel of Figure 8, for the case in which we run the simulations with a time span consistent with the 10-year sovereign spread. Consistent with the design of the simulation experiment, the sample used to compute the correlations is the 1994Q12015Q4 one. In Figure 8 it is easy to see that the correlation increases monotonically with the level of debt, until it reaches a maximum when the debt threshold is $54 \%$, displaying a coefficient of close to 0.8 .

In this context, a natural question that arises is whether the debt threshold has changed over time, and in particular, to what extent the crisis has affected the debt level that is perceived as sustainable by the market. In order to answer this question, we apply the procedure sequentially starting with a minimum sample size and extending it until the whole sample is considered, allowing us to study the temporal evolution of the debt threshold. The results of this latter exercise are shown in in the right panel of Figure 8 and indicate that the estimated debt threshold has been quite stable in the interval $50 \%-55 \%$ of GDP all over the sample since the beginning of the European Monetary Union. 
Figure 8: The "prudent" public debt threshold

Correlation between the sovereign spread and the different public debt thresholds

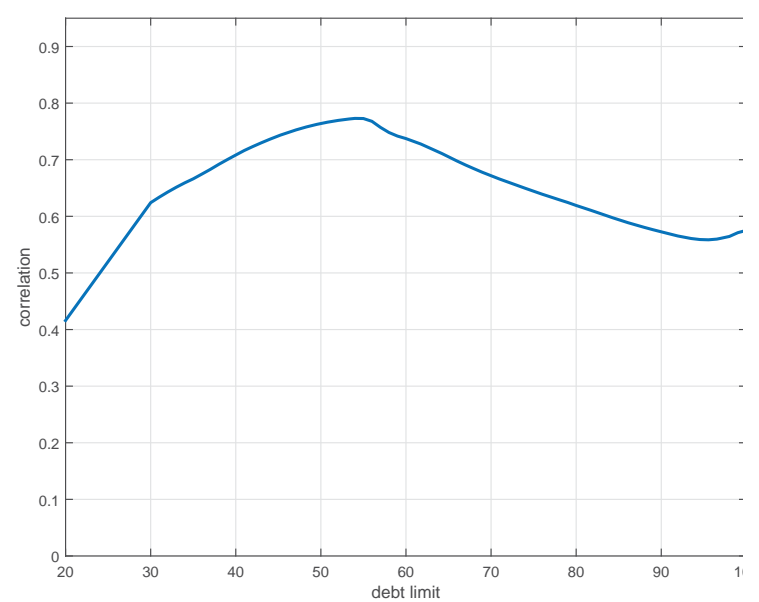

Time variation of the public debt threshold that maximizes the correlation with the spread

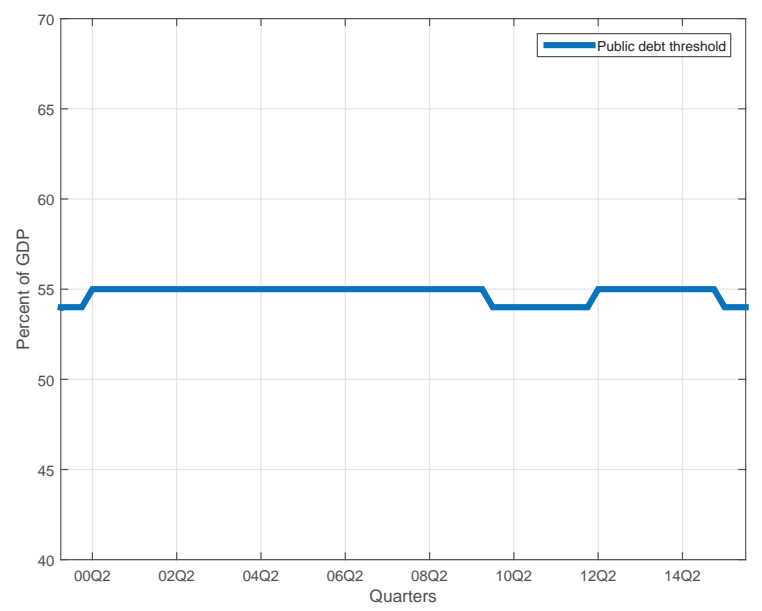

In a final exercise we test whether or not the probability measure Granger-causes the market risk indicator, $S_{t}$. To do so, we run regressions of the kind:

$$
S_{t}=\Gamma(L) S_{t-1}+\Phi(L) P_{t / t-1}^{T}(\theta)+\epsilon_{t}
$$

We show some selected results in Table 3, for the computed probabilities of breaching the $60 \%$ limit. The table presents Granger Causality tests between $S_{t}$ and $P_{t / t-1}^{10 y}(60)$, and between $S_{t}$ and $P_{t / t-1}^{10 y}(54)$. We show the specification for 4 lags (the results are robust to this choice) and different sample sizes. In addition, we show in the table the tests for $P_{t+1 / t}^{10 y}(60)$ and $P_{t+1 / t}^{10 y}(54)$. This is warranted as the leaded variable is contemporaneous with respect to $S_{t}$ from the point of view of the moment in time in which it is known to the analyst. This is so because the measure $P_{t / t-1}^{10 y}(\theta)$ is the probability computed for quarter $t$ with data and estimated parameters up to $t-1$, and as a consequence, its information content is lagged with respect to $S_{t} \cdot{ }^{7}$ From the results in the table, $P_{t / t-1}^{10 y}(60)$ Granger-Causes $S_{t}$, and also when $P_{t+1 / t}^{10 y}(\theta)$ is forwarded, for all specifications (i.e. the null hypothesis of no causation gets rejected). The results in Table 3 indicate that the probability measures contains real-

\footnotetext{
${ }^{7}$ In this respect, one could nowcast $Y_{t}$ for the current quarter $t$ by means of monthly indicators, and update $P_{t / t-1}$ with more timely information.
} 
Table 3: Granger-causality tests: probability measures and sovereign spread.

\begin{tabular}{lccc|ccc} 
& \multicolumn{3}{c}{$P_{t / t-1}^{10 y}(60)$} & \multicolumn{3}{c}{$P_{t / t-1}^{10 y}(54)$} \\
$p$-values, 4 lags & $1994 \mathrm{Q} 1-$ & $1994 \mathrm{Q} 1-$ & $1994 \mathrm{Q} 1-$ & $1994 \mathrm{Q} 1-$ & $1994 \mathrm{Q} 1-$ & $1994 \mathrm{Q} 1-$ \\
& $2015 \mathrm{Q} 4$ & $2013 \mathrm{Q} 4$ & $2007 \mathrm{Q} 4$ & $2015 \mathrm{Q} 4$ & $2013 \mathrm{Q} 4$ & $2007 \mathrm{Q} 4$ \\
\hline$P_{t / t-1}^{10 y}(\theta)$ does not Cause $S_{t}$ & $0.0010^{a}$ & $0.0013^{a}$ & $0.0000^{a}$ & $0.0015^{a}$ & $0.0015^{a}$ & $0.0000^{a}$ \\
$S_{t}$ does not Cause $P_{t / t-1}^{10 y}(\theta)$ & $0.0019^{a}$ & $0.0015^{a}$ & $0.0000^{a}$ & $0.0489^{b}$ & $0.0524^{c}$ & $0.0000^{a}$ \\
\hline$P_{t / t-1}^{10 y}(\theta)$ does not Cause $S_{t}$ & $0.0006^{a}$ & $0.0016^{a}$ & $0.0000^{a}$ & $0.0003^{a}$ & $0.0006^{a}$ & $0.0009^{a}$ \\
$S_{t}$ does not Cause $P_{t / t-1}^{10 y}(\theta)$ & $0.0013^{a}$ & $0.0007^{a}$ & $0.0000^{a}$ & $0.0394^{b}$ & $0.0337^{b}$ & $0.0000^{a}$ \\
\hline
\end{tabular}

Note: ${ }^{a}$ : null hypothesis rejected at the $1 \%$ level, ${ }^{b}: 5 \%,{ }^{c}: 10 \%$.

time, leading indicator value. Compared to $S_{t}$, our measures do have the advantage of being based on macro fundamentals, and thus they are less affected than $S_{t}$ from episodes of excess volatility or non-fundamental-based reactions by the markets.

\section{Conclusions}

In this paper we extend previous work that combines the Value at Risk approach with the estimation of the correlation pattern of the macroeconomic determinants of public debt dynamics by means of Vector Auto Regressions. These estimated VAR's are then used to compute the probability that the public debt ratio exceeds a given threshold, by means of Montecarlo simulations.

We apply this methodology to Spanish data and compute time-series probabilities to analyze the possible correlation with market risk assessment, measured by the spread with respect to the German bond. Taking into account the high correlation between the probability of passing a pre-specified debt threshold and the spread, we go a step further and ask what would be the threshold that maximizes the correlation between the two variables. Thus, by pursuing this approach, we are able to gauge the implicit debt threshold or "prudent debt level" which is consistent with market expectations as measured by the sovereign yield spread. 


\section{References}

Aiyagari S. R. and E. R. McGrattan (1998), "The Optimum Quantity of Debt", Journal of Monetary Economics, 42, 447-469.

Bi, H. (2012), "Sovereign Default Risk Premia, Fiscal Limits and Fiscal Policy", European Economic Review, 56, pp. 389-410.

Bi, H. and E. Leeper (2013), "Analyzing Fiscal Sustainability". Bank of Canada Working Paper, 2013-27.

Collard, F., M. Habib and J. Rochet (2015), "Sovereign Debt Sustainability in Advanced Economies". Journal of the European Economic Association, 13, pp. 381-420.

de Castro, F., F. Martí, A. Montesinos, J. J. Pérez, A. J. Sánchez-Fuentes (2016), "A quarterly fiscal database fit for macroeconomic analysis", mimeo, Bank of Spain. Previous version available as Bank of Spain Working Paper 1408.

Daniel, C. B. and C. Shiamptanis (2013), "Pushing the limit? Fiscal policy in the European Monetary Union", Journal of Economic Dynamics and Control, 37, pp. 2307-2321.

Desbonnet, A. and S. Kankamge (2007), "Public debt and aggregate risk", Documents de travail du Centre d'Economie de la Sorbonne 2007-42.

Fall, F. and J.-M. Fournier (2015), "Macroeconomic uncertainties, prudent debt targets and fiscal rules", OECD Economics Department Working Papers, no 1230.

Floden M. (2001), "The effectiveness of government debt and transfers as insurance", Journal of Monetary Economics, 48, 81-108.

Ghosh, A., J. Kim, E. Mendoza, J- Ostry and M. Qureshi (2015), "Fiscal Fatigue, Fiscal Space and Debt Sustainability in Advanced Economies", The Economic Journal, 123, pp. F4F30.

Gordo, L., Hernández de Cos, P. and J. J. Pérez (2013), "Developments in Spanish public debt since the start of the crisis". Bank of Spain Economic Bulletin, July-August, pp. 19-36. 
Hernández de Cos, P. and J. J. Pérez (2013), "The new budgetary stability law". Bank of Spain Economic Bulletin, April, pp. 13-25.

Hiebert, P., J. J. Pérez and M. Rostagno (2009), "The trade-off between public debt reduction and automatic stabilisation", Economic Modelling, 26, pp. 464-472.

Kleven H.J. and C.T. Kreiner (2003), "The role of taxes as automatic destabilizers in New Keynesian economics", Journal of Public Economics, 87, pp. 1123-1136.

Leeper, E. M. and T. B. Walker (2011), "Fiscal Limits in Advanced Economies", NBER Working Papers 16819, National Bureau of Economic Research, Inc.

Martí, F. and J. J. Pérez (2015), "Spanish public finances through the financial crisis", Fiscal Studies, 36, pp. 527-554.

Mendoza, E. and P. M. Oviedo (2006), "Fiscal Policy and Macroeconomic Uncertainty in Developing Countries: The Tale of the Tormented Insurer", NBER Working Papers 12586, National Bureau of Economic Research, Inc.

Polito, V.and M. Wichens (2011), "A model-based indicator of the fiscal stance", European Economic Review, 56, pp. 526-551.

Woodford M. (1990), "Public Debt as Private Liquidity", American Economic Review, 80, pp. 382-388. 


\title{
BANCO DE ESPAÑA PUBLICATIONS
}

\author{
WORKING PAPERS
}

1530 CRISTINA FERNÁNDEZ and PILAR GARCÍA PEREA: The impact of the euro on euro area GDP per capita.

1531 IRMA ALONSO ÁLVAREZ: Institutional drivers of capital flows.

1532 PAUL EHLING, MICHAEL GALLMEYER, CHRISTIAN HEYERDAHL-LARSEN and PHILIPP ILLEDITSCH: Disagreement about inflation and the yield curve.

1533 GALO NUÑO and BENJAMIN MOLL: Controlling a distribution of heterogeneous agents.

1534 TITO BOERI and JUAN F. JIMENO: The unbearable divergence of unemployment in Europe.

1535 OLYMPIA BOVER: Measuring expectations from household surveys: new results on subjective probabilities of future house prices.

1536 CRISTINA FERNÁNDEZ, AITOR LACUESTA, JOSÉ MANUEL MONTERO and ALBERTO URTASUN: Heterogeneity of markups at the firm level and changes during the great recession: the case of Spain.

1537 MIGUEL SARMIENTO and JORGE E. GALÁN: The influence of risk-taking on bank efficiency: evidence from Colombia.

1538 ISABEL ARGIMÓN, MICHEL DIETSCH and ÁNGEL ESTRADA: Prudential filters, portfolio composition and capital ratios in European banks.

1539 MARIA M. CAMPOS, DOMENICO DEPALO, EVANGELIA PAPAPETROU, JAVIER J. PÉREZ and ROBERTO RAMOS: Understanding the public sector pay gap.

1540 ÓSCAR ARCE, SAMUEL HURTADO and CARLOS THOMAS: Policy spillovers and synergies in a monetary union.

1601 CHRISTIAN CASTRO, ÁNGEL ESTRADA and JORGE MARTÍNEZ: The countercyclical capital buffer in Spain: an analysis of key guiding indicators.

1602 TRINO-MANUEL ÑíGUEZ and JAVIER PEROTE: Multivariate moments expansion density: application of the dynamic equicorrelation model.

1603 ALBERTO FUERTES and JOSÉ MARÍA SERENA: How firms borrow in international bond markets: securities regulation and market segmentation.

1604 ENRIQUE ALBEROLA, IVÁN KATARYNIUK, ÁNGEL MELGUIZO and RENÉ OROZCO: Fiscal policy and the cycle in Latin America: the role of financing conditions and fiscal rules.

1605 ANA LAMO, ENRIQUE MORAL-BENITO and JAVIER J. PÉREZ: Does slack influence public and private labour market interactions?

1606 FRUCTUOSO BORRALLO, IGNACIO HERNANDO and JAVIER VALLÉS: The effects of US unconventional monetary policies in Latin America.

1607 VINCENZO MERELLA and DANIEL SANTABÁRBARA: Do the rich (really) consume higher-quality goods? Evidence from international trade data.

1608 CARMEN BROTO and MATÍAS LAMAS: Measuring market liquidity in US fixed income markets: a new synthetic indicator.

1609 MANUEL GARCÍA-SANTANA, ENRIQUE MORAL-BENITO, JOSEP PIJOAN-MAS and ROBERTO RAMOS: Growing like Spain: 1995-2007.

1610 MIGUEL GARCÍA-POSADA and RAQUEL VEGAS: Las reformas de la Ley Concursal durante la Gran Recesión.

1611 LUNA AZAHARA ROMO GONZÁLEZ: The drivers of European banks' US dollar debt issuance: opportunistic funding in times of crisis?

1612 CELESTINO GIRÓN, MARTA MORANO, ENRIQUE M. QUILIS, DANIEL SANTABÁRBARA and CARLOS TORREGROSA Modelling interest payments for macroeconomic assessment.

1613 ENRIQUE MORAL-BENITO: Growing by learning: firm-level evidence on the size-productivity nexus.

1614 JAIME MARTÍNEZ-MARTÍN: Breaking down world trade elasticities: a panel ECM approach.

1615 ALESSANDRO GALESI and OMAR RACHEDI: Structural transformation, services deepening, and the transmission of monetary policy.

1616 BING XU, ADRIAN VAN RIXTEL and HONGLIN WANG: Do banks extract informational rents through collateral?

1617 MIHÁLY TAMÁS BORSI: Credit contractions and unemployment. 
1618 MIHÁLY TAMÁS BORSI: Fiscal multipliers across the credit cycle.

1619 GABRIELE FIORENTINI, ALESSANDRO GALESI and ENRIQUE SENTANA: A spectral EM algorithm for dynamic factor models.

1620 FRANCISCO MARTÍ and JAVIER J. PÉREZ: Spanish public finances through the financial crisis.

1621 ADRIAN VAN RIXTEL, LUNA ROMO GONZÁLEZ and JING YANG: The determinants of long-term debt issuance by European banks: evidence of two crises.

1622 JAVIER ANDRÉS, ÓSCAR ARCE and CARLOS THOMAS: When fiscal consolidation meets private deleveraging.

1623 CARLOS SANZ: The effect of electoral systems on voter turnout: evidence from a natural experiment.

1624 GALO NUÑO and CARLOS THOMAS: Optimal monetary policy with heterogeneous agents.

1625 MARÍA DOLORES GADEA, ANA GÓMEZ-LOSCOS and ANTONIO MONTAÑÉS: Oil price and economic growth: a long story?

1626 PAUL DE GRAUWE and EDDIE GERBA: Stock market cycles and supply side dynamics: two worlds, one vision?

1627 RICARDO GIMENO and EVA ORTEGA: The evolution of inflation expectations in euro area markets.

1628 SUSANA PÁRRAGA RODRÍGUEZ: The dynamic effect of public expenditure shocks in the United States.

1629 SUSANA PÁRRAGA RODRÍGUEZ: The aggregate effects of government incometransfer shocks - EU evidence.

1630 JUAN S. MORA-SANGUINETTI, MARTA MARTÍNEZ-MATUTE and MIGUEL GARCÍA-POSADA: Credit, crisis and contract enforcement: evidence from the Spanish loan market.

1631 PABLO BURRIEL and ALESSANDRO GALESI: Uncovering the heterogeneous effects of ECB unconventional monetary policies across euro area countries.

1632 MAR DELGADO TÉLLEZ, VÍCTOR D. LLEDÓ and JAVIER J. PÉREZ: On the determinants of fiscal non-compliance: an empirical analysis of Spain's regions.

1633 OMAR RACHEDI: Portfolio rebalancing and asset pricing with heterogeneous inattention.

1634 JUAN DE LUCIO, RAÚL MÍNGUEZ, ASIER MINONDO and FRANCISCO REQUENA: The variation of export prices across and within firms.

1635 JUAN FRANCISCO JIMENO, AITOR LACUESTA, MARTA MARTÍNEZ-MATUTE and ERNESTO VILLANUEVA: Education, labour market experience and cognitive skills: evidence from PIAAC.

1701 JAVIER ANDRÉS, JAVIER J. PÉREZ and JUAN A. ROJAS: Implicit public debt thresholds: an empirical exercise for the case of Spain.

\begin{tabular}{|r|c|}
\hline BANCODE ESPAÑ & $\begin{array}{c}\text { Unidad de Servicios Auxiliares } \\
\text { Alcalá, 48 - 28014 Madrid } \\
\text { E-mail: publicaciones@bde.es } \\
\text { www.bde.es }\end{array}$ \\
\hline
\end{tabular}

